Paper to be presented at the 37th Research Conference on Communication, Information and Internet

Policy (TPRC), Arlington, VA, 25-27 September 2009

\title{
How Competitive is the Canadian Residential Broadband Market? \\ A Study of Canadian Internet Service Providers and Their Regulatory Environment
}

\author{
Catherine Middleton \& Annemijn van Gorp \\ Ted Rogers School of Management \\ Ryerson University \\ [catherine.middleton; avangorp]@ryerson.ca
}

\begin{abstract}
This paper offers a detailed assessment of the state of competition in the Canadian residential broadband market. After examining barriers to entry, the nature of rivalry in pricing and services, and the extent to which competitors can develop a sustainable position in the market, it concludes that the Canadian market does not foster effective competition. Canadian consumers do not have access to a range of differentiated services, and there is little innovation in the market. The paper offers some suggestions on ways to increase competitiveness in the broadband market, and concludes that changes to the current market structure are required to enable the development of more innovative broadband services in Canada.
\end{abstract}

Keywords: Broadband, DSL, cable broadband, competition, regulation, Canada

\section{Introduction}

With nearly ubiquitous cable and telephone networks across Canada, as well as mandated service-based competition on DSL and cable platforms, theories of facilities- and service-based competition suggest that Canada should have a competitive, innovative market for residential broadband Internet access and services. But despite assertions by the Canadian Radio-television and Telecommunications Commission (Canada's telecommunications regulatory authority, known as the CRTC) that the Canadian communications services market "generally operates in a competitive environment" (Canadian Radio-television and Telecommunications Commission, 2009a, p. ii), evidence suggests that the residential broadband market is dominated by incumbent telco and cable providers offering near-identical services with throttled bandwidth and 
internationally non-competitive prices. Additionally, investment in next generation network infrastructure (e.g. fibre to the home) lags behind many OECD countries. This suggests that the current regulatory framework, which is driven by the CRTC's mandate to rely on market forces "to the maximum extent feasible" (Canadian Radio-television and Telecommunications Commission, 2009a, p. 5), fails to achieve desired results; namely a competitive and innovative market that offers high quality, affordable broadband to Canadians.

Given this market context, this paper has two purposes. It begins with an empirical investigation of the residential broadband market in Canada, in order to provide insights into the actual state of competition in the market in 2009 (twelve years after local loop unbundling was first mandated, and ten years after open access to cable networks was granted), and to answer the question as to whether the current approach to competition is resulting in innovation and consumer choice. Factors that are encouraging and deterring competition and innovation among providers are identified. Reaching the conclusion that effective competition is not in place in the Canadian broadband market, the paper then considers the implications of this finding. Possible remedies to improve competitiveness in the market are considered, followed by a discussion of the future of service-based competition in Canada.

The paper provides data from an ongoing study of the Canadian residential broadband market, conducted by the two authors. To date, we have interviewed 27 stakeholders from British Columbia, Alberta, Saskatchewan, Manitoba, Ontario, Québec and Nova Scotia. Respondents include representatives of large for-profit corporations (e.g. incumbent telcos), smaller independent for-profit and non-for-profit ISPs, provincial agencies responsible for broadband development, alliances of ISPs and community broadband advocates. We are continuing to conduct interviews with industry stakeholders, and anticipate that we will be able to provide supplementary data and analysis at the time of the conference.

The paper begins with a brief discussion of theories of competition, and the provides data on the Canadian broadband market. We then present data from our interviews with Internet service providers and other industry stakeholders, outlining the nature of facilities- and service-based competition in the Canadian broadband market, and explaining the challenges faced by servicebased competitors trying to establish differentiated product offerings. The paper then offers some suggestions for improving market competitiveness, and concludes with the observation that without changes to the current market environment, the prospects for the development of 
innovative, faster broadband networks in Canada are not good.

\section{Background}

\subsection{Motivation for the Research}

This paper explores the nature of competition in the retail and wholesale residential broadband ${ }^{1}$ market in Canada. Canadians were early adopters of broadband services (Lie, 2003), but in recent years, Canada has ceded its position at the top of OECD rankings (Organisation for Economic Co-operation and Development, 2009a). In the 1990s and early 2000s, the Canadian federal government actively promoted a "Connecting Canadians" agenda that encouraged Internet access and use (Chretien, 2000; Industry Canada, 1994; Manley, 1999). But the 2001 National Broadband Task Force's recommendations for extending broadband services to all Canadian communities by 2004 were not fully implemented (National Broadband Task Force, 2001), and a 2006 recommendation to extend broadband availability to unserved areas was not acted upon (Telecommunications Policy Review Panel, 2006), suggesting that the commitment to "connecting Canadians" had disappeared from the federal government agenda.

Now, in late 2009, the Canadian federal government is implementing a program to extend connectivity to underserved and unserved areas (Industry Canada, 2009). This is an important initiative, but does not address the development of faster networking capacity across the country. Unlike many other countries that are enacting or preparing strategies to encourage the development and effective usage of much higher capacity broadband networks, and to enable citizens' full participation in the information economy (see for example Department for Culture Media and Sport \& Department for Business Innovation and Skills, 2009; Federal Communications Commission, 2009; KBS World, 2009; Prime Minister of Australia, 2009), there is currently no comparable Canadian strategy to encourage these outcomes in Canada. ${ }^{2}$

${ }^{1}$ This study focuses on the provision of broadband to individuals, not businesses. 'Residential broadband' encompasses service to individuals' homes, as well as mobile service that is purchased by individuals for personal use. In Canada, entry level broadband products (marketed as 'broadband lite') offer download speeds of $256 \mathrm{Kbps}$. For the purposes of this study, connections at or above $256 \mathrm{Kbps}$ are considered to be broadband connections, but it is noted that in $2008,76 \%$ of Canadian broadband users subscribed to speeds at or above 1.5 Mbps (Canadian Radio-television and Telecommunications Commission, 2009a).

${ }^{2}$ Industry Minister Tony Clement held a forum on 'Canada's Digital Economy' in mid-2009 (see http://www.ic.gc.ca/eic/site/ecic-ceac.nsf/eng/h_gv00526.html), with the goal of 'advanc[ing] the digital economy in Canada' but no formal strategy has been proposed in this regard. 
It is within this context that we are undertaking a study of competition in the Canadian residential broadband market. Canadians have had access to broadband services for many years now, and the regulatory environment is structured in a way that should encourage competition. The role of competition in developing broadband markets has been researched extensively by telecommunications scholars, ${ }^{3}$ with the general conclusion being that competition, especially competition on different platforms (e.g. DSL vs. cable), can promote broadband uptake and encourage the development of high quality, innovative services. Policy makers throughout the OECD have embraced competition as a means of developing broadband infrastructure (OECD Directorate for Science Technology and Industry, 2008; Organisation for Economic Cooperation and Development, 2008). As such, in a world where broadband is now considered as “essential infrastructure for participating in today's economy" (Industry Canada, 2009), it is important to understand whether the regulatory environment in Canada is enabling competition, and how (or whether) competition is actually fostering the development of this important essential infrastructure.

Simply creating a regulatory environment that allows for competition does not ensure that effective competition will follow. Effective competition is characterized by rivalry in pricing and services, requires low barriers to entry for new providers, and enables competitors to hold "a reasonably sustainable market position" (Australian Competition \& Consumer Commission, 2009, p. 38). Additionally, the $\operatorname{OECD}$ (2008, p. 49) observes that "the fastest connections, lowest prices and most innovative services are in areas where there is a range of consumer choices for broadband."

The objective of this paper then is to assess the state of competition in the Canadian residential broadband market, with a view to understanding whether the regulatory environment is actually enabling competition, and if so, if competition is able to deliver positive outcomes (e.g. choice and innovation) for Canadian broadband consumers. We begin with the question of whether effective competition is present in the Canadian market. After determining that this is not the case, we discuss potential remedies that might encourage more effective competition in Canada, and thus lead to the availability of improved broadband services. We conclude with consideration of the implications of a non-competitive market with respect to the development of

\footnotetext{
${ }^{3}$ Baranes and Bourreau (2005), Bourreau and Doğan (2004), Distaso et al. (2006) and Höffler (2007) (among others) offer reviews of this literature.
} 
broadband infrastructures that will meet Canadians' needs in the future.

\subsection{Competition in Broadband Markets}

This section offers a brief overview of the types of competition found in broadband markets, to provide context for our assessment of the Canadian market. Facilities-based competition is created when broadband services are provisioned using a variety of different infrastructures. In the US and Canada, a range of facilities-based providers enable individuals to access broadband services using wired (DSL, fibre, cable) or wireless ${ }^{4}$ (fixed wireless, Wi-Fi, 3G, HSPA, satellite) connections.

Service-based competition is created through the provision of broadband access using existing facilities. For instance, market entrants can compete for customers at the retail level by providing service over unbundled local loops, the copper lines that connect a household to the incumbent local exchange carrier's facilities (OECD Directorate for Science Technology and Industry, 2003). Regulatory provisions to enable service-based competition using unbundled local loops are in place in all OECD countries except Mexico (Organisation for Economic Cooperation and Development, 2009b). Service-based competition can also be achieved by allowing entrants to provision broadband services using cable infrastructures, but this is less common. Many countries do not have an extensive cable network, and in some countries that do, like the United States, access to cable infrastructure is not mandated. In Canada, cable companies are mandated to allow market entrants to provide broadband connectivity using cable infrastructure (Canadian Radio-television and Telecommunications Commission, 1999).

Facilities-based competition has been preferred as a means of increasing broadband uptake and encouraging investment in infrastructure (Baranes \& Bourreau, 2005; Bourreau \& Doğan, 2004; Denni \& Gruber, 2007; Distaso, et al., 2006; Organisation for Economic Co-operation and Development, 2009b), but service-based competition is recognized as a useful intermediary (Christodoulou \& Vlahos, 2001). The ladder of investment theory (Cave, 2006; European Regulators Group, 2005) suggests that service-based competition allows market entrants to gain a position in the market, establish a customer base, and over time develop sufficient revenues to enable them to invest in their own infrastructure. Because access to their own infrastructure

\footnotetext{
${ }^{4}$ See Coutts (2008), and Johnston and Aghvami (2007) for descriptions of wireless broadband infrastructure.
} 
allows for more control of their products and enables greater innovation, it is the desired longterm market outcome. But by encouraging service-based competition, the presence of new entrants can speed up the provision of competition in the market and promote the development of better broadband services across the market.

In the Canadian context, facilities-based competition is favoured by the regulator (Canadian Radio-television and Telecommunications Commission, 2009a, p. 5). But as will be described below, facilities-based competition in the Canadian broadband market can be characterized as a duopoly, with a single telephone company and a single cable company as the main competitors in local markets. ${ }^{5}$ Service-based competition offers a way for additional companies to enter the Canadian market, but in comparison to other countries (e.g. in the EU, see European Regulators Group, 2005), service-based competitors in Canada have not been very successful in winning market share from the facilities-based competitors. An overview of the Canadian broadband market is provided below, followed by an in-depth assessment of competition in the market.

\section{The Canadian Broadband Market Environment}

There are approximately 500 companies in the Canadian 'Internet access industry' (Canadian Radio-television and Telecommunications Commission, 2009a, p. 5). Consistent with the CRTC's terminology, we consider all of these companies to be 'Internet service providers' (ISPs). Incumbent telecommunications service providers (telcos) comprise $9 \%$ of the industry, and we refer to these as ILECs (incumbent local exchange carriers). The largest of these are Telus, SaskTel, MTS, Bell, Télébec and Bell Aliant. Each offers phone and Internet services in a specific geographic area, and some ILECs also now offer competitive products (e.g. wireless service, business Internet access) in various markets across the country. Shaw, Cogeco, Rogers and Vidéotron are among the largest cable companies, and with their smaller counterparts the cablecos make up $18 \%$ of the industry. $54 \%$ of the companies in the industry are described by the CRTC as 'resellers,' purchasing access to facilities on a wholesale basis from telcos and cablecos. We use the term 'independent ISP' to describe these companies (who often do more than just resell services). The remaining $19 \%$ are utility telcos, municipalities and other service

\footnotetext{
${ }^{5}$ In the Canadian market, competition is based on geography. Although there are multiple ILECs and cable companies who provide broadband services, the cable companies do not compete against each other, nor do the ILECs, as each serves a discrete geographic region.
} 
providers who own infrastructure.

With 500 Internet service providers, it could be assumed that the Internet access market is a competitive one, however the CRTC reports that five companies - Bell, Telus, Rogers, Vidéotron and Shaw - collectively earned $76 \%$ of the retail Internet access revenues in 2008. Even more striking is the fact that $94.5 \%$ of residential broadband subscribers in Canada get their Internet service from an ILEC or cableco, leaving only $5.5 \%$ of the market to independent ISPs. Although $95 \%$ of local telephone lines are eligible for unbundling, fewer than $5 \%$ are currently being used by market entrants to provide competitive services (Organisation for Economic Cooperation and Development, 2009b).

The CRTC "strives to ensure the provision of reliable and affordable telecommunications services of high quality accessible to both urban and rural area customers" (Canadian Radiotelevision and Telecommunications Commission, 2009a, p. 5). It has been directed to "rely on market forces to the maximum extent feasible as the means of achieving the telecommunications policy objectives" (Governor General in Council, 2006), and to encourage facilities-based competition where possible. Although facilities-based competition does provide most Canadians with a choice of DSL or cable broadband, ${ }^{6}$ compared to other OECD countries the prices for connectivity are relatively high, and the access speeds are slow. The OECD's methodology has been criticized, ${ }^{7}$ but their data show that Canada's position as a broadband leader has been declining for years.

Pricing information from late 2008 ranked Canadian prices for connections at speeds greater than $12 \mathrm{Mbps}$ as 2nd highest in the OECD, and speeds of 2.5 to $10 \mathrm{Mbps}$ were ranked as 8th most expensive (Organisation for Economic Co-operation and Development, 2009b). The CRTC notes that more than half of Canadian broadband subscribers have a connection that can deliver download speeds greater than 5 Mbps (Canadian Radio-television and Telecommunications Commission, 2009a), but a 2008 study reporting on actual download and upload speeds found that these speeds are not being realized (Angani, Kim, Guleri, \& Misawa, 2008). Akamai (2009) reported that the average speed of Canadian Internet connections to its global server network was

\footnotetext{
${ }^{6} 89 \%$ of the Canadian population had access to DSL service in 2007 , and $93 \%$ had access to cable modems (Organisation for Economic Co-operation and Development, 2009b).

${ }^{7}$ See for example Blackwell (2009) regarding pricing, and Market Clarity (2007) and Ford et al. (2007) regarding the overall approach.
} 
less than $4 \mathrm{Mbps}$, with only $23 \%$ of connections established at speeds of $5 \mathrm{Mbps}$ or greater. Finally, testimony before the CRTC's Internet Traffic Management Hearing ${ }^{8}$ in July 2009 indicated that several ISPs place speed restrictions on their retail and/or wholesale services, meaning that such provider are not delivering their advertised speeds to their customers.

These observations suggest that the Canadian broadband market is not providing particularly fast or cheap broadband services, and justify further investigation of whether competition in the Canadian market place is 'effective competition.' In the section that follows, we explore the actual state of competition in the Canadian residential broadband market. This requires an exploration of the wholesale and retail broadband markets, with a view to understanding the extent of rivalry in the market, whether new entrants are able to establish sustainable businesses (and if not, what the barriers to entry and ongoing business development are), and whether there is innovation in service offerings. The section begins with an overview of the types of broadband providers in the Canadian market, and the offers a detailed exploration of the scope of facilitiesand service-based competition among Canadian ISPs.

\section{Is the Canadian Broadband Market Competitive?}

As has been explained above, the Canadian broadband market is served by incumbent telcos (ILECs) and cablecos, and independent ISPs. The primary facilities-based competitors are the ILECs and cablecos. Although wireless and satellite providers are theoretically in competition with ILECs and cablecos, in practice there is minimal competition between fixed line (DSL/cable) and wireless providers because fixed line connections are generally cheaper, faster and more reliable than wireless connections. For the estimated $94 \%$ of Canadians with access to a fixed line connection (Canadian Radio-television and Telecommunications Commission, 2009a), there would be no compelling reason to consider adopting a satellite or fixed wireless connection. On the mobile side, cellular carriers are investing heavily in the development of mobile broadband services. Mobile broadband may appeal to some individuals as an additional, secondary service that supplements a fixed-line connection, but to date it does not offer speeds or pricing that would make it competitive with fixed line connections. In sum, facilities-based competition pits cable broadband service against DSL in the areas where fixed connections are

\footnotetext{
${ }^{8}$ Transcripts of the Public Hearing on Telecom Public Notice CRTC 2008-19 are available online at http://www.crtc.gc.ca/eng/transcripts/2009/index.htm.
} 
available, and pits wireless, mobile and satellite providers against each other where fixed connections are unavailable.

This paper focuses on competition among fixed line service providers, ${ }^{9}$ which involves the ILECs, cablecos, and independent ISPs who either own their own facilities or purchase access from the ILECs and cablecos (referred to hereafter as the incumbents). Data presented in this section are drawn from a subset of our respondents, including community broadband advocates, representatives of ILECs and of for-profit and not-for-profit independent ISPs, operating in the provinces of British Columbia, Alberta, Saskatchewan, Manitoba, Ontario and Québec. ${ }^{10}$

Table 1: Facilities-Based Broadband Providers in Canada

\begin{tabular}{|c|c|c|c|}
\hline & Provider and Market & Nature of Competition & $\begin{array}{l}\text { Market } \\
\text { Share* }\end{array}$ \\
\hline DSL & $\begin{array}{l}\text { Incumbent telcos (ILECs) serve } \\
\text { specific geographic locations. }\end{array}$ & $\begin{array}{l}\text { No competition among incumbent telcos, } \\
\text { competition for cable providers. }\end{array}$ & $39 \%$ \\
\hline Cable & $\begin{array}{l}\text { Cablecos serve specific } \\
\text { geographic locations. }\end{array}$ & $\begin{array}{l}\text { No competition among cablecos, } \\
\text { competition for DSL providers. }\end{array}$ & $51 \%$ \\
\hline $\begin{array}{l}\text { Fibre to the } \\
\text { home } \\
\text { (FTTH) }\end{array}$ & $\begin{array}{l}\text { Very few providers to date, some } \\
\text { projects serve multiple unit } \\
\text { dwellings. }\end{array}$ & $\begin{array}{l}\text { Competition for DSL and cable, but very } \\
\text { minimal impact given limited } \\
\text { availability. }\end{array}$ & \multirow{4}{*}{$3 \%$} \\
\hline $\begin{array}{l}\text { Wireless } \\
\text { (fixed } \\
\text { wireless, Wi- } \\
\text { Fi) }\end{array}$ & $\begin{array}{l}\text { Many independent providers, } \\
\text { serving rural and remote areas. }\end{array}$ & $\begin{array}{l}\text { Provides minimal competition to DSL } \\
\text { and cable, competitor for satellite. }\end{array}$ & \\
\hline Satellite & $\begin{array}{l}\text { Smaller providers, serving rural } \\
\text { and remote areas, } 100 \% \text { coverage } \\
\text { of the Canadian market. }\end{array}$ & $\begin{array}{l}\text { Provides minimal competition to DSL } \\
\text { and cable, competitor for wireless. }\end{array}$ & \\
\hline $\begin{array}{l}\text { Mobile } \\
\text { (3G, HSPA) }\end{array}$ & $\begin{array}{l}\text { Provided by wireless carriers } \\
\text { (incumbent telcos), serves urban } \\
\text { and some rural areas. }\end{array}$ & $\begin{array}{l}\text { Generally a secondary service, } \\
\text { minimally competitive with DSL and } \\
\text { cable, but a competitor for wireless and } \\
\text { satellite. }\end{array}$ & \\
\hline Dial-up & $\begin{array}{l}\text { Not a broadband service. Many } \\
\text { independent providers, serving } \\
\text { urban, rural and remote areas. }\end{array}$ & $\begin{array}{l}\text { Minimal competition for all other } \\
\text { providers, in rural and remote areas dial- } \\
\text { up may be the only affordable option. }\end{array}$ & $7 \%$ \\
\hline
\end{tabular}

*Data source: CRTC (2009a). These figures represent the percentage of the Canadian residential Internet access market (not the broadband market) served by each type of provider. Note that the DSL figure includes both incumbent and independent DSL providers. The cable figure includes TPIA providers.

${ }^{9}$ We are also collecting data on the provision of broadband services to areas where there is no fixed line provider. The issues involved in this type of service provision are quite different from provision of fixed line service, and will be considered in a separate paper. It is more difficult to serve this segment of the market. Communities tend to be smaller and further apart, making it difficult to achieve economies of scale. Provincial governments have taken an active role in supporting service provision to smaller communities, providing incentives and subsidies to enable providers to establish viable business models to serve these customers.

${ }^{10}$ Unless otherwise noted, all quotes are drawn from interviews conducted by the authors with representatives of these organizations. Identifying information has been removed. 
As noted earlier, the ILECs and cablecos serve $94.5 \%$ of the Canadian broadband market with their own branded service offerings, thus facilities-based competition between ILECs and cablecos dominates the market (e.g. Bell versus Rogers in Ontario, Telus versus Shaw in Alberta). Table 1 provides an overview of the facilities-based residential broadband providers in Canada, and notes the nature of competition faced by each type of provider.

Within the DSL market, there is service-based competition between the ILECs and independent ISPs (e.g. Bell or Telus versus independents like Teksavvy or Distributel). Independents using third party Internet access (TPIA) over cable networks compete with the cablecos from whom they get service (e.g. Cybersurf versus Shaw). Service-based competition is also possible between independent ISPs who are providing service using wholesale DSL access (e.g. Teksavvy versus Distributel). Table 2 describes the types of service-based broadband products available to independent ISPs, and outlines the nature of competition enabled when these service-based offerings are deployed.

Table 2: Service-Based Broadband Access in Canada

\begin{tabular}{|l|l|l|}
\hline & Type of Access & Nature of Competition \\
\hline $\begin{array}{l}\text { TPIA (Third } \\
\text { Access) }\end{array}$ & Wholesale cable product, not widely used. & $\begin{array}{l}\text { Competition for DSL and } \\
\text { cableco offerings, but very } \\
\text { minimal impact. }\end{array}$ \\
\hline DSL - resale & $\begin{array}{l}\text { Wholesale DSL product, independents resell as } \\
\text { "white label" DSL. }\end{array}$ & $\begin{array}{l}\text { Competition for incumbent telco } \\
\text { and cableco offerings, minimal } \\
\text { differentiation is possible. }\end{array}$ \\
\hline $\begin{array}{l}\text { DSL - retail } \\
\text { service }\end{array}$ & $\begin{array}{l}\text { Wholesale aggregated DSL product (e.g. Bell's } \\
\text { Gateway Access Service), enables independents to } \\
\text { provide access to many customers with minimal } \\
\text { interconnection points. }\end{array}$ & $\begin{array}{l}\text { Competition for incumbent telco } \\
\text { and cableco offerings, minimal } \\
\text { differentiation is possible. }\end{array}$ \\
\hline $\begin{array}{l}\text { DSL - } \\
\text { dedicated } \\
\text { service }\end{array}$ & $\begin{array}{l}\text { Wholesale aggregated DSL product (e.g. Bell's } \\
\text { independents to serve business customers. }\end{array}$ & $\begin{array}{l}\text { Competition for incumbent telco } \\
\text { and cableco offerings, higher } \\
\text { level of differentiation is } \\
\text { possible. }\end{array}$ \\
\hline Co-location & $\begin{array}{l}\text { Wholesale DSL, independent installs equipment in } \\
\text { telco central office. }\end{array}$ & $\begin{array}{l}\text { Competition for incumbent telco } \\
\text { and cableco offerings, enables } \\
\text { differentiated service offerings. }\end{array}$ \\
\hline
\end{tabular}

\subsection{Facilities-Based Competition in Canada}

Incumbent telcos describe the retail broadband markets in which they offer DSL services as being "fiercely competitive." Cablecos and ILECs are vying to be the sole provider of telecommunications, Internet and entertainment services for their customers - one ILEC reports 
a broadband market share of $40 \%$, compared to $60 \%$ for its cable rival, and states that "From our perspective we face a very competitive marketplace. In the battle for digital home, we have a very formidable competitor with [the cableco]." Noting that "reasonable economists disagree whether two big players plus some smaller players is enough", the informant stated that "from our perspective, we face a very competitive environment, very..." Across the country, the CRTC reports that ILECs have 39.5\% market share in the residential broadband market, and the cablecos 55\% (Canadian Radio-television and Telecommunications Commission, 2009a). We can conclude that both the ILECs and cablecos have established a sustainable position in the market, and that they compete for market share.

With respect to rivalry for prices and services however, many of the independent ISPs felt that the duopolistic nature of the market meant that competition between ILECs and cablecos was friendly rather than intense. As an operator of a small independent ISP that was unable to create a sustainable business noted:

In some ways there's some competition. But it's more like it's a duopoly. They're racing, but the two horses are looking each other in the eye and winking, and they're saying "ok let's both slow down, and we can both keep going and have a good day."

It is suggested that the ILECs and cablecos have a comfortable position in the market, and without effective competition from other provides have been complacent in developing new services. As another respondent argued, "as far as I'm concerned, one or two competitors are not enough to get you the level of competition to drive prices down and see innovative and new speeds and faster services happen in the retail market." The ILECs and cablecos offer incremental upgrades in speeds and service, and provide deals on bundled services (voice, Internet, TV). They respond to each other, but neither is taking the lead on more innovative service offerings, as three of our interviewees explain below.

They're competing on how to get a bundle, how to get digital TV over your Internet, stuff like that. How to get insurance so you don't go over your bandwidth cap, that's what they're competing on. "Sign up for two years and get 5\% off." They're smart, they're making money. But in terms of actually changing their technology fundamentally or really increasing speeds, or doing innovative things like wireless, not really, not really.

It's one-upmanship, if anything. Cable comes up with a 7 megabit service, so [the ILEC] comes up with an 8 megabit service, so cable comes up with a 10 megabit service, so [the ILEC] comes up with a 12 megabit service. But they're not trying to build the infrastructure out, they're just trying to be one step ahead of the other guy. 
Right now if you have a look at what has been happening in the Internet access markets with the major [telco and cableco] players, they have been upgrading their networks, but they haven't been trying to push into any of the higher speeds, because they're making money off what they're currently doing. Unless there's some external stimulus that would require them to offer much better speeds than they currently do, there isn't motivation to push the fibre access closer to the customer.

Thus, while facilities-based competition is fueling a fight for market share between the ILECs and cablecos, the competition is waged on the basis of service packages and minor performance improvements, rather than on innovative new product offerings. Facilities-based competition has enabled the provision of broadband services to most Canadian homes, but it has not encouraged ongoing innovation in service delivery, and has not enabled truly effective competition in the marketplace. We now turn to service-based competition, to consider whether it is effective in the Canadian residential broadband marketplace.

\subsection{Service-Based Competition in Canada}

The ILECs and cablecos provide $94.5 \%$ of residential broadband connections in Canada, leaving $5.5 \%$ share for independent ISPs. In terms of market size, this $5.5 \%$ represents approximately 500,000 subscribers, compared to the 8.5 million served by the ILECs and cablecos (Canadian Radio-television and Telecommunications Commission, 2009a). The presence of service-based competitors in this market indicates that it is possible to develop a sustainable market position, but our respondents indicated that this is not easy.

Among the independent ISPs we interviewed, we found that most offered more than one type of service. In addition to offering Internet access, some provide other Internet-based services like web design and web hosting, some are competitive local exchange carriers (CLECs) and others also resell mobile telephony services. Many still offer dial-up services, ${ }^{11}$ a small number are experimenting with providing fibre to the home (FTTH), some offer wireless services, and the majority offer DSL, generally provisioned using an ILEC's aggregated wholesale service. We have no reliable source regarding the numbers of independents offering cable modem service (TPIA), but the general consensus among our respondents is that this is much less common than wholesale DSL, for reasons that will be discussed below.

The major competition for independent ISPs is between the independents' DSL offerings and

${ }^{11}$ Dial-up service is not just for people who can't access a broadband connection. Even in urban centres, a not-forprofit ISP notes that "there is a real demand and we get new membership daily, just requesting dial-up access." 
the broadband services provided by the ILECs and cablecos. Competition among independents exists, but generally the independents view each other as allies:

We tend to work together with lots of small players, we share problems, we do deals with each other where it makes economic sense, we tend not to have an adversarial relationship at all with any of the other smaller CLECs. I think we get along quite well with most of the CLECs operating out there. The main threat to our business would be the ILEC and the cable companies.

As Canadians have switched from dial-up services to broadband, the market share of independents has decreased (Canadian Radio-television and Telecommunications Commission, 2009a) resulting in a much less competitive market. Asked about the current state of competition in the Canadian broadband market, one respondent replied:

I don't know how competitive I could even say it is today. If you look back in the dialup days, the independent ISPs made up a very large chunk of the competitive market. It was actually independent ISPs that started dial-up Internet. The ILECs came later to that market. So at one time there were many, many, many players in that broadband access market. Now it's almost primarily the cable companies and the phone companies.

Another respondent added that:

There's a long list of failed ISPs in Canada, and a very small handful that are left. And the ones that are left are all supporting themselves by serving rural customers outside the cable plant footprint. And they're doing it with wireless. And in the case of wireless they could make some money. They can buy the gear and they can set it up and pay it off and they can get a positive cash flow out of it. Unlike the reselling of ADSL, which is basically one of Canada's failures, as a country was to regulate the sale of ADSL properly to create a market for the new competitors, it didn't happen.

We found a great deal of frustration among independents who had been in the market for some time. They made it clear that it is very difficult to compete with the ILECs and cablecos, despite the regulations that allow access to their facilities. As one respondent said, talking about the lack of profitability in providing DSL services, "I might as well have been selling washers and dryers. There are endless things I should have done instead of being an ISP, really there are just a few of us left." The continued existence of independent ISPs appears somewhat tenuous, thus it is difficult to conclude that they will continue to have a sustainable position in Canada's residential broadband market.

Canada's regulatory environment does provide independents with a variety of options for accessing ILECs' and cablecos' infrastructure. If this environment is fostering competition 
effectively, we would expect to see low barriers to entry, and rivalry on pricing and services would result in faster connections, competitive pricing and innovative services. The ladder of investment theory suggests that as independent ISPs enter the market, they would begin by making extensive use of cableco and/or ILEC facilities. With effective competition, it should be easy to enter the market, and as the independents build up a revenue base, they can reduce their reliance upon the facilities of others, and invest in their own infrastructure.

It is difficult to get detailed information on exactly how independent ISPs access cablecos' and ILECs' facilities in Canada, ${ }^{12}$ however a review of CRTC hearings and decisions reveals that the relationships between facilities providers and market entrants are contentious. While the facilities providers generally (but not always ${ }^{13}$ ) adhere to the letter of the regulator's rules, they have sufficient power over independents seeking access to their networks to make entry difficult, and to reduce the likelihood that the independents can develop viable businesses based on an access model. Without the ability to develop thriving businesses by reselling service or using wholesale access to facilities, the independents are unable to invest in their own infrastructures, and are thus unable to truly differentiate themselves in the market.

\subsubsection{Access to Cable Infrastructure: TPIA}

We have not found many independent ISPs who have been successful in providing broadband services using the cablecos' infrastructure (TPIA). ${ }^{14}$ When asked why this is the case, independents describe high costs and technical limitations (the service is described as being "rife with problems"), cableco wholesale divisions that are difficult to deal with, and low margins if service is actually provided. ILECs offer a service that allows an independent ISP to connect to their network in a single location, but with the cable companies:

You have to make multiple inter-connection points to light up the footprint. You have to actually lease bandwidth to multiple places. In the case of [a local cableco], it's upwards of 20 or 25 different places that you have to lease connections to. To be able

\footnotetext{
${ }^{12}$ This information has been requested by the CRTC, as part of Notice of Consultation 2009-261 (Canadian Radiotelevision and Telecommunications Commission, 2009c).

${ }^{13}$ CRTC records contain many requests from independent ISPs that the CRTC enforce their orders regarding access and conditions of access to cable or telco infrastructures (e.g. Canadian Radio-television and Telecommunications Commission, 2004; Canadian Radio-television and Telecommunications Commission, 2009d).

${ }^{14}$ Cybersurf does offer cable-based broadband services in Western Canada, and some ISPs in Québec also use TPIA.
} 
to light up their footprint, it would take a lot of money up front without any customers.

...So there was a lot of grief back and forth trying to set up with TPIA services.

Even persistent ISPs have found it difficult to gain access to cable networks. As one independent told us, "You really had to go and bang on the door of the cable companies, repeatedly, continuously, and they would throw every barrier they could think of in front of you, to trip you up, because they did not want to open up their network to anyone else. And they succeeded." Another ISP suggested that the cableco serving his region "doesn't even get out of bed to make an attempt. They don't want ISPs, they don't want wholesale business, they have no wholesale division that I know of. I know that they're complying with the CRTC in some way or another, ... [but] you'll see that they don't have any business partners." Yet another referred to the "onerous" nature of the contractual agreement that would be required to establish access, noting that "It might have lived up to the letter of what the CRTC had hoped for, but it certainly didn't live up to the spirit." It is difficult to establish a working relationship with a cableco, but even if access can be negotiated, "the margins are just not there." Our research leads us to concur with a respondent who concluded that "the cable company service, hardly any ISPs actually use it," even though "it would be nice to have two suppliers and play them off against one another."

\subsubsection{Access to the Local Loop: DSL Infrastructure}

TPIA has not resulted in robust competition between independent ISPs and cable and telco facilities owners, but access to the ILECs' infrastructure has proven to be somewhat easier. As will be documented below, competition does exist between independent ISPs and facilities owners. Although the ILECs certainly have created barriers to entry, and are making it increasingly difficult for entrants to differentiate their services, the independents and the ILECs see their relationship as being somewhat symbiotic. An ILEC explains that "we try to have a positive relationship. We try to cultivate as positive a relationship with those folks as we can." An independent who deals with multiple ILECs says that:

We're a competitor to [the ILEC's] retail side, but at the same time we're also an ally to [its] retail side. People who would normally leave [the ILEC's] retail to go to cable have essentially come to us as a last ditch effort, so we end up being their [the ILEC's] win back area as well. It's kind of hard to describe ourselves as direct competitor to [them], right?

\subsubsection{Types of Access}

There appear to be three main ways in which independent ISPs are providing DSL service in 
the Canadian market. The simplest is a pure resale arrangement. Described as a "white label" product, the billing relationship is between an independent ISP and its residential customers, but the entire DSL connection is owned and managed by another provider. Effectively, this is "[the provider's] product with a different name."

The second option, which appears to be the most widely used, allows independent ISPs to connect to any customer in an ILEC's network by installing equipment in a single location rather than in each local exchange where the independent has customers. This type of service is described as a "virtual pipe that creates a pathway from the customer's home to the ISP's office, its point of presence." This virtual pipe aggregates data from the local loop over the ILEC's network to the ISP. At the point of interconnection between the ILEC and the ISP, "it's the ISP who then has to take that traffic, put it onto its own router equipment, and then route the traffic onto the Internet." This means that it is the independent, not the ILEC, that is providing the backhaul (the Internet service for the end customers). The independent has a choice of two service levels, one that offers the service over the ILEC's retail network, and the other that offers a dedicated service. ${ }^{15}$ The first service level is less expensive, and is the one that is generally used for residential connections. The dedicated service offers some additional technical flexibility (including the ability to bypass the ILEC's traffic management practices) but is considered to be too expensive to use as the base for serving residential customers. Additionally, some independent ISPs offer a resale version of this aggregated service to smaller market entrants for whom establishing their own backhaul and interconnection arrangements would be cost prohibitive.

The third option is for an independent to co-locate its own DSL equipment in an ILEC's local exchange (also called the central office). This requires the most capital expenditure, but provides maximum flexibility for the independent in terms of offering a differentiated service. The ladder of investment theory suggests that market entrants will gradually transition from aggregated services to co-location over time, as they establish a customer base. In the section that follows, we outline some of the challenges noted by independent ISPs as they attempt to build long-term,

\footnotetext{
${ }^{15}$ Bell's version of these services are known as Gateway Access Service (GAS) and High Speed Internet Access Service (HSA) (Bell, 2009). Telus calls its services Wholesale Internet ADSL Service (Carrier Access Tariff, Other Competitor Services, item 226 http://about.telus.com/publicpolicy/tariffs/docs2/CRTC214_6/Carrier_9/Section_18/item226.pdf), and Wide Area Network ADSL service (Carrier Access Tariff, Other Competitor Services, item 227 http://about.telus.com/publicpolicy/tariffs/docs2/CRTC214_6/Carrier_9/Section_18/item227.pdf).
} 
sustainable businesses using existing facilities to provide DSL to their own customers. We begin by considering the barriers to competition related to the market power of the ILECs and cablecos, consider multiple issues regarding provision of DSL using the ILECs' aggregated services and then address the challenges in using co-location to provision independents' customers. Finally, we describe difficulties that independents face in interacting with the regulator and understanding the regulatory environment.

\subsubsection{Incumbent Market Power}

Regardless of how an independent plans to provision DSL service, the first issue it faces in establishing its business is to attract customers. Independent ISPs' competition for broadband customers comes from "the ILEC and the cable company. Full Stop." This means that the business practices of these incumbents can have a significant impact on the independents' ability to gain new customers, and to retain their existing customers. Many independents do not (and cannot) offer a suite of services comparable to the 'triple play' (landline, TV and Internet) or 'quad play' (triple play plus mobile phone) offerings of the incumbents, thus some customers choose to do business with the incumbents as they "perceive that they get better value." Other independents complain that incumbents "telemarket to all our customers" and also note that they give away computers to entice new customers. One independent concludes that "It's impossible

to compete in the ADSL market. There is no competition. There's just a bunch of companies going broke, they're on their way out."

\subsubsection{Providing DSL using an ILEC's Wholesale Aggregated DSL Service}

As independents move beyond a pure reselling arrangement to provision their DSL customers, a number of issues arise regarding use of an ILEC's wholesale aggregated service. As was noted, with this arrangement, independent ISPs must provide backhaul to connect their customers to the Internet, and must work with the ILEC that provides service in the territory where the independents' customers are located. It is noted that if independents want to provide DSL, working with an ILEC offers "the only service that you can use to get to certain customers. There are no substitutes." An independent notes that "We would happily buy from somebody else if it was available," but the challenge of buying service from anyone other than the ILEC is that other providers are not able to offer connectivity to all customers in the ILEC's footprint. 
There are people that do some wholesale like that, but their footprints will be small. For example, just in the Toronto telephone exchange, there are 20 central offices. There are very few people who light them up. So to go to another ISP to get service from them, we'd have to still have the [ILEC] arrangement to get the coverage that we need, there's probably nobody that does Sudbury or Sault Sainte Marie, or Fort Erie, Niagara Falls [smaller cities and towns in Ontario], or stuff like that.

The advantages of being able to access customers across wide geographic areas using the ILECs' infrastructure are offset by the practical, day to day challenges of actually being able to provide service over this infrastructure. Many respondents reported on tactics used by the ILECs to delay or otherwise complicate service provision, making it difficult for the independents to provide good service to their end customers. For instance:

[The ILEC] does many insidious things to delay connecting new customers. An example is the protocol for changing ISPs. You used to be able to run two DSL services on one line. So you could connect the second service, and then disconnect [the ILEC] once it was clear the new service was working. Now this isn't allowed any more. [The ILEC] requires a full billing cycle (30 days) notice to cancel DSL, so it ends up being a 45 day wait. If the new service provider is not apparent, [the ILEC] now cancels DSL completely, and removes the [DSL] card from the exchange. Customers can end up without Internet during the switch, and the consumer has to do more work to get it right.

The CRTC has issued various orders to the ILECs to provide services to independents. In response, the incumbents often appeal the decisions. One independent describes this as an abuse of process and notes "they're very successful at it."

They've been told five times that they have to supply services to such as us, they're argued four times and have been told five times 'No.' They didn't like that answer so they've gone to the Government and said "We think this is wrong, so as a political issue, as a Government of Canada issue, we shouldn't be forced to sell to these small competitors, we want them off our back." And what they've been able to do, is now the Government of Canada comes back to the CRTC and says "ok, we want this whole issue reviewed, for the $6^{\text {th }}$ time, and we will make a decision by December."

These business practices highlight the challenges for the independents operating in "a subservient situation." "The less flexibility that we have in defining the terms and conditions of our relationship with a customer, the less value there is for us from a customer's point of view." This issue of flexibility in defining the terms and conditions of service is a critical one, and it is the subject of a number of proceedings currently before the CRTC. In a market with effective competition, new entrants are able to create differentiated products, and to compete with incumbents on the basis of services offered, speeds and pricing. In the segment of the Canadian 
market where independents use the ILECs' aggregated DSL service, there are few opportunities for differentiation. The ILECs are requesting that the CRTC allow them to reduce these opportunities further, and in some instances these requests have been granted. For instance, the ILECs have been allowed to implement traffic shaping on the networks serving independent ISPs' customers (Canadian Radio-television and Telecommunications Commission, 2008b), and will soon be able to implement usage-based billing which forces the independents to implement download caps for their customers (Canadian Radio-television and Telecommunications Commission, 2009e). At the time of writing, there are several appeals and ongoing proceedings related to these matters (e.g. Canadian Radio-television and Telecommunications Commission, 2008a, 2009c), but it is clear that use of the aggregated DSL product imposes limits on the services that independents can provide to their customers.

Independents can differentiate their offerings on the basis of customer service and contractual arrangements for service. For instance, some independents reported offering higher levels of customer service than the ILECs, with more technical support staff and with personal touches like answering the phones rather than using an automated system. Independents may choose to offer service without the long term contracts often required by ILECs and cablecos, and they may have different policies regarding customers' credit ratings. They can allow their customers to operate servers and to share their connections with others. These aspects of the independents' offerings do provide value, as this independent notes:

If customers want diversity, resellers [independent ISPs] play an important role in differentiating themselves from the ILEC, that's the only way they can stay in business. Sure they may use the same access and the same last mile, but there are other things beside the last mile that are important to customers.

But from a technical perspective, there are very few real opportunities to provide innovative services. As one ISP asks, "how do you differentiate yourself from [the ILEC], when you're selling [the ILEC's] service? It is very, very difficult and damn near impossible." Independents are more likely than the ILECs to promote 'dry line' DSL services (a service that does not require an active landline telephone subscription), but when using an aggregated DSL product they are subject to the ILECs' retail practices for Internet throttling ${ }^{16}$ and billing, making

\footnotetext{
${ }^{16}$ The CRTC's July 2009 Internet Traffic Management Hearings revealed that Bell is the only ILEC that currently applies traffic management tools. The tools are used to slow the types of certain Internet traffic at particular times of day, and apply to Bell's own retail customers and to customers of their GAS wholesale service. Their
} 
technical innovation very difficult.

The throttling we live with now because we have no choice. The bandwidth caps, we probably will be forced to do it because [the ILEC] will bill us a usage fee, and I don't think the economics of that product offering would withstand us just eating that usage fee without passing it along to the customers. So we may be forced into doing it depending on what happens with the CRTC proceeding, ${ }^{17}$ but we're fighting it, because we wouldn't necessarily choose to do it.

The independents are frustrated with the ILECs' actions, arguing that they are "taking control down to the user level, into their own hands, where really this is a wholesale agreement, and that control should be left to us [the independents]." The ILECs' traffic management practices "take tools away from the ISP, and that's wrong. The ISP should choose himself how he wants to shape his traffic, it shouldn't come pre-shaped from Bell. That sucks."

The ILECs have been ordered by the CRTC to offer the same speeds to their wholesale DSL customers as they offer to their own retail customers (Canadian Radio-television and Telecommunications Commission, 2009d), but they have not complied and are appealing this decision to the Federal Cabinet (Telecommunications Policy Branch, 2009). For many customers, these characteristics of the last mile of their Internet connection are important, and the fact that independent ISPs cannot provision competitive services using aggregated DSL access is problematic. But in a submission to the CRTC, Bell, one of the Canadian ILECs, argues that if independents want to avoid the restrictions on DSL services, they have other choices in the way that they provision their networks:

Internet service providers (ISPs) have other options than purchasing access under Bell's GAS Tariff. They are free to lease unbundled local loops, to invest in colocation and Digital Subscriber Line Access Multiplexers (DSLAMs), to subscribe to wholesale Internet high speed access service from cable carriers through third party Internet access (TPIA) or to build their own networks. All of these options would avoid any traffic management activity by Bell. They can also purchase High Speed Access (HSA) which is not subject to traffic management. (Bell Canada, 2008)

As noted earlier, TPIA is not a workable option for many independent ISPs. And for various reasons described above and below, it is very difficult for most independent ISPs to make the extensive investments needed to establish co-location sites, or to build their own networks. The

more expensive HSA service is not subject to traffic shaping. Transcripts of the public hearing are available online at http://www.crtc.gc.ca/eng/transcripts/2009/index.htm.

${ }^{17}$ Since this interview took place, permission has been granted to Bell Canada and Bell Aliant to impose usagebased billing on its GAS customers (Canadian Radio-television and Telecommunications Commission, 2009e). 
theory of service-based competition that results in investment in new facilities over the longer term requires that market entrants are able to develop sustainable businesses and build up a critical mass of customers by using the existing facilities. What appears to be happening in Canada is that the incumbents are trying to discourage market entrants from using their facilities, but in moving quickly in this regard, the market entrants have not had sufficient time to build up the capital required to invest heavily in their own infrastructure, as this quote illustrates.

A few years back Industry Canada was auctioning off spectrum, in the $3.5 \mathrm{Ghz}$ band, and we actually participated in the auction, trying to buy spectrum across Ontario and Québec to do broadband Internet on our own wireless infrastructure. We were basically pushed out by [the ILEC], we had got to the last bidding round and everybody had dropped out of the bidding except [us and the ILEC]. The last bid we had made was a $\$ 9,000,000$ bid for spectrum, and [the ILEC] upped the bid and for us it was too much money. We're only a $\$ 45,000,000$ company, so bidding $\$ 9,000,000$ just for a license for the air to deploy a network... whereas [the ILEC] is a multibillion dollar entity... We actually did try to do that because we wanted to try to get off relying on TPIA or wholesale DSL.

\subsubsection{Providing DSL by Co-Locating}

Our data show that independents who have tried to co-locate in ILECs' facilities have not always found this to be an easy proposition. There are benefits to co-locating, for instance the ISPs "get to keep a much greater percentage of the revenue associated with each DSL customer," and have much greater control over the speeds that they can offer their customers. To the best of our knowledge however, only a few independents have done extensive co-location, while others have been testing the waters by trying to co-locate in just a few exchanges where they do have enough customers to justify the needed investment. Here is a comment on the experiences of a large independent ISP regarding co-location:

To try to do it on a national scale would cost a fortune. In the case of Toronto, there's 20 of them we would have to build, and that just does Toronto - that's not Mississauga, that's not Ajax, and that's not Richmond Hill - it's just the Toronto exchanges, and there's 20 of them. You know, that's a multi-million dollar capital outlay to light those up. Then we have the backhaul from each one, and in our case, for our approximately 8,000 DSL customers that we have, they're probably spread out across about 500 different Bell central offices. There's no way we could light up that type of footprint - not with a customer base of 8,000 , given the capital cost to actually roll-out a co-location. We had tried two, as an experiment from a marketing perspective and a technical perspective. We built one in Ottawa, and one in Montreal. And it's a challenge.

Another independent notes that: 
while the co-location tariff is very affordable, and it sort of makes sense price-wise, the problem is that [the ILEC] has found its way to sidestep the intent of the tariff and they make the practical side of co-location much more expensive than the tariff implies. I think that unless the CRTC is more forceful about enforcing its ability to regulate the monopoly providers in the market, I think [the ILEC] will continue to do what is the letter of the law rather than the intent of the law.

In terms of additional expenses, independents must buy general liability insurance (\$25 million coverage required), cover the cost of utilities and pay leasing charges for space and equipment. One respondent commented that "It's not like [the ILEC] has an incentive to get the co-location site up quickly. When you're talking about turning up a co-location site, it can take 2 months to a year, the more likely average is 6-8 months."

Another issue related to co-location is the possibility that the investment in equipment may be 'stranded' (Organisation for Economic Co-operation and Development, 2009b). DSL connections work over copper networks. But as ILECs push fibre connectivity deeper into the customer access network, the copper connecting the end customer to the ILEC no longer terminates in the central office. The upgraded fibre connection between the ILEC and the customer bypasses the central office, connecting instead from a remote location that is closer to the customer. The question of whether independents will be allowed to install their equipment in the ILECs' remotes is currently being appealed to the Federal Cabinet (MTS Allstream Inc, 2009). However, even if ILECs are mandated to allow market entrants to install equipment at remote locations, there are physical space constraints that make this very difficult. As one independent explains:

They don't have any room in there to put anybody else's equipment, or they don't have the ability to have somebody else get into it, either for access reasons or security reasons or just purely space reasons. Well, some number like $40 \%$ of customers are not served from the central office because there's a distance limitation on DSL, so they're served from one of these little huts. If right away, $40 \%$ of your customers are served from the little hut you can't even put any equipment in, then that limits your ability to deploy services.

Central offices serve thousands of customers, but remotes only serve hundreds. While it is viable for an independent to serve 300-400 customers using their own equipment installed in one central office, if the same number of customers need to be served from remote locations the independent would need to install equipment in multiple remotes used to connect these same customers. This makes it much less economical for independents to use their own equipment, and the refusal of the ILECs to offer matching speeds for wholesale aggregated DSL products 
means that residential customers who want to have a fast connection must choose the ILEC's service over an independent's. One respondent suggests that the ILECs' strategy is “to keep ISPs on a legacy ADSL infrastructure, and deny them access to higher speeds. ... They will not be able to provide services like IPTV, or other types of 'triple play' services, a complete bundle, video, voice, Internet."

\subsubsection{Regulatory Challenges}

A final issue for independent ISPs seeking access to incumbents' facilities regards their ability to interact with and engage the CRTC. The regulatory environment is complex. As has been demonstrated, there are many appeals to the CRTC by both the incumbents and the independents, arguing for what each group perceives to be a better, fairer means of enabling market entrants to have access to existing facilities. The disagreements between the two sides are frequent and fractious. Although the CRTC is considered to have "done a good job of hiring people, and informing itself of issues," both sides have been critical of CRTC rulings.

There is a power difference between the incumbents and the independents. The incumbents have greater resources at their disposition, and use them to subject the CRTC to "daily pressure and lobbying." For the independents, "every battle we fight is an uphill battle with the regulator to get them to take our side." "Getting our viewpoint heard and understood in a way that fits in with the format that the CRTC expects their applications in is very difficult." As a representative of one of the larger independent ISPs explains:

The ability for [the incumbents] to participate in these proceedings, and the lobbying efforts of the government, are beyond the ability of [the independents]. [The ILECs] have a regulatory team of - I don't know how many people - we have 2 guys that spend part of our time doing regulatory, but most of it trying to run the business. Plus we don't lobby - we don't go for lunch with the Industry minister. ... I think [the ILECs] have the Commission's ear, and their message comes out stronger than ours.

The delaying strategies of the incumbents in responding to regulatory orders have already been noted. It takes time to consider appeals, and the impact of delays in regulatory decisions can have a much more serious impact on independent ISPs than on the incumbents, as this ISP's comment explains:

Some of these [CRTC] proceedings have been held up for over a year. Can you imagine being held up behind your customer for a year? "Ok, we're going to have a fair race, everyone start. You the little guys, you stand over there. We're going to tie you up in knots, we're going to lash you to the starting line, and then we're going to 
fire the starting gun. And then we're going to untie you about 3/4 of the way into the race, and let you try to catch up to the other guys." Well how often do you think you're going to win? Never. And that's the model. So it's a flawed model. There is no single ruling that they can make, or have made, that is going to fix this model.

\subsection{Summary}

This section has offered an extensive description of the nature of competition in the Canadian residential broadband market. As noted throughout, the question of interest here is whether the regulatory environment is enabling competition, and whether competition is resulting in innovation and choice for Canadian broadband consumers. Using criteria outlined earlier to identify the presence of "effective competition," Table 3 provides an assessment of the competitiveness of various market segments. When effective competition exists in a residential broadband market, it should be possible for participants to establish a sustainable market position. Barriers to entry should be low, and rivalry in price and service should lead to faster connections, lower prices and innovative product and service offerings.

The market does appear to be sufficiently competitive to allow a number of providers to establish a position in the market. But changes in the conditions of wholesale aggregated DSL access are constraining the independents' ability to differentiate the services they offer, and this may make it more difficult for them to sustain their market position in the longer term. It is not particularly easy to enter the market. Financial barriers to entry can be quite high (especially if developing new facilities), but technical and 'procedural' (e.g. incumbent delaying tactics) barriers are also a concern. It is also difficult for market entrants that only provide broadband service to compete with incumbents' triple and quad play service packages. There is some rivalry among providers, but incumbents are not observed to be competing intensely on price or speed, instead focusing their competitive activities on encouraging their customers to adopt additional services. ${ }^{18}$ Service-based competitors using wholesale aggregated DSL have very little room to compete on price, and a limited ability to offer innovative, differentiated services.

${ }^{18} \mathrm{An}$ issue that has not been addressed is that of demand for higher speed broadband services. Incumbents told us that they are not currently activating higher network speeds, because they do not believe that there is market demand for such services. But what is unknown is the impact that effective competition might have in decreasing prices and increasing demand for higher speed services. It might be that more intense competition would encourage incumbents to accelerate the deployment of higher speed services. 


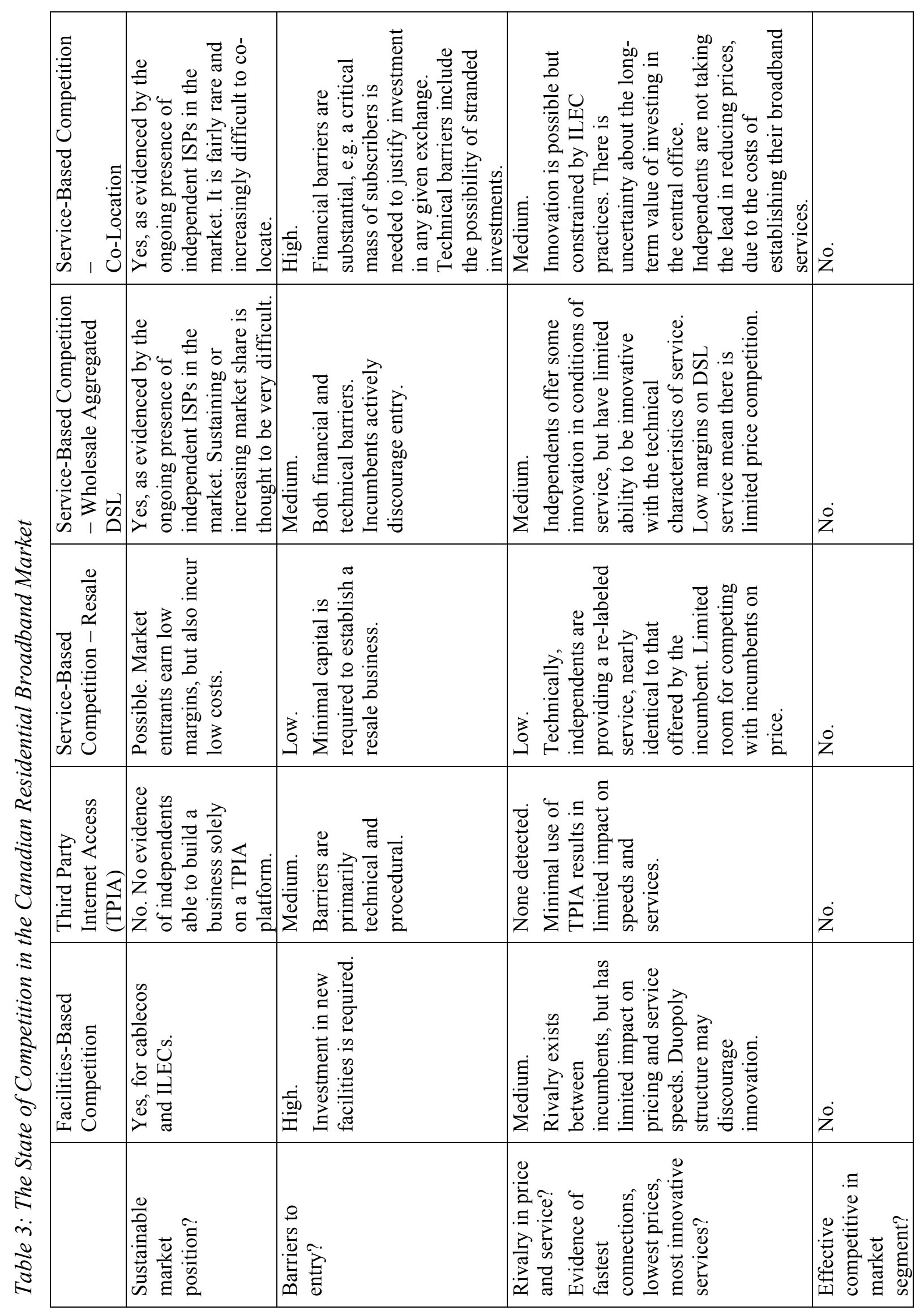


Co-location does offer more flexibility in terms of providing faster speeds or differentiating services (e.g. no throttling), but is cost prohibitive for most independent ISPs. Overall, the data presented here, as summarized in Table 3, lead to the conclusion that the Canadian residential broadband market place does not currently exhibit, foster or support effective competition in any of its segments.

In the next section, we consider possible actions that could be taken to increase the competitiveness of the Canadian residential broadband market, with a view to encouraging more rivalry on price and service, and the development of higher speed networks. We also consider the future of service-based competition in Canada.

\section{Discussion}

The Canadian broadband market demonstrates the truth in the OECD's statement that "having access to broadband and having access to a number of competitive broadband providers are quite different" (Organisation for Economic Co-operation and Development, 2008, p. 49). One of our respondents commented that:

We have had anemic broadband competition and we're living with the consequences. We have some of the lowest broadband speeds in developed countries, OECD countries, and we have some of the highest rates of the OECD countries. Don't take it from me, there are lots of studies out there that show a pattern.

Our research supports the OECD's statement that "it has proven extremely difficult in some OECD countries to reduce the bottleneck control of incumbents over the local loop and access to this loop" (OECD Directorate for Science Technology and Industry, 2003, p. 4). The independent ISPs with whom we spoke repeatedly illustrated the ways in which their ability to provide competitive services using the incumbents' infrastructure is constrained by the incumbents' action. This is not a surprising finding, as such behaviours have been reported elsewhere (see for example Bourreau \& Doğan, 2004; Van Gorp, Maitland, \& Hanekop, 2006; Whalley \& Curwen, 2008). Our respondents offered some suggestions as to how the overall functionality of the market could be improved. These are presented below, followed by a brief discussion on the future of service-based competition in Canada.

\subsection{Increasing Competitiveness in the Canadian Residential Broadband Market}

We frequently heard from our respondents that there is a need to promote competition, and 
that competition must involve more than incumbent ILECs competing against incumbent cablecos. There is a sense of urgency among the independent ISPs, who believe that action must be taken quickly rather than played out in a continued series of proceedings before the CRTC (which is what seems to be happening at present). In contrast, it is suggested that among the general public "no one seems to care [about high prices for broadband]. There's just no public outcry, it's just not a hot issue for the public, which would then influence politicians." If changes to telecommunications policy are necessary to foster innovation and improve the quality of broadband connections in Canada, then increased public awareness of the issues could help in developing support for new policies.

\subsubsection{Establish Consistent Public Policy Regarding Broadband Network Deployment and Use}

As was mentioned at the outset, more than a decade ago Canada was a leader in actions and policies designed to foster citizens' participation in the information society. Policies were in place to encourage infrastructure development and usage, but over time these were abandoned, and have not been replaced. Since 2002, there have been a few individual federal initiatives aimed at increasing broadband supply in unserved areas, but there is no national digital strategy or overarching plan regarding the ongoing development of broadband infrastructure in the country .

In order to give broadband providers some certainty in the market place, an incumbent made a strong plea for the federal Government to abandon "one off" programs (like the current initiative for funding new rural and remote broadband projects). The case was made for "consistency in federal public policy," to allow all stakeholders in the market to understand the rules guiding broadband provision, and to enable them to develop long term strategies and investment plans accordingly.

\subsubsection{Provide Effective Regulation of Wholesale Broadband Access}

The role of the CRTC is to "regulat[e] and supervis[e] the broadcasting and telecommunications systems in Canada" (Canadian Radio-television and Telecommunications Commission, 2009b). While some respondents believe policy changes are needed to make the market more competitive, others believe that the current regime can support competition if regulation were improved. One respondent felt that the CRTC already has a well-defined 
mandate to encourage and enable competition and that it simply needs to do a better job of monitoring the wholesale market:

I think that the CRTC does have the ability and the discretion given to it by the policy direction, to actually make the findings that are needed to get a decent level of competition happening in the retail market. Just by regulating wholesale services properly. All it needs - it doesn't need to regulate the retail market - it just needs to properly regulate the wholesale market, and it's not doing that.

Many respondents noted the importance of treating the wholesale market differently that retail markets, and argued that wholesale products should be available from facilities-providers without any sorts of restrictions (e.g. traffic shaping, download caps). As one independent ISP said, "the commission has to understand that the wholesale service is different, and it has to be treated differently, and it's only then that we'll be able to fully differentiate ourselves." In situations where a service provider serves wholesale and retail customers, one means of ensuring that there is no direct connection between their wholesale and retail service offerings is to require some sort of separation between these two lines of business.

\subsubsection{Enable Structural Separation and Open Access}

Many respondents promoted the idea of separating the provision of wholesale broadband service from the provision of retail broadband, to avoid the "grief of the retail "Internet provider in bed with the infrastructure provider." This approach has been taken in other jurisdictions (e.g. UK, New Zealand) and appears to be working effectively. As one respondent suggested:

We need one set of companies that owns the infrastructure, but does not sell services. We've done this with gas and electricity, we structurally separated the gas and electricity networks about 20 years ago, and that was very successful. So now the company that owns the gas line, pipeline, does not also sell gas to you. The same with electrical transmission lines. We need to do that in telecom, have different companies own the infrastructure, separate from those who sell services.

Others also called for open access to facilities, removing the power of those who built the networks to determine the conditions of access and instead allowing any provider to deliver (for a negotiated fee) any service over the customer access network.

\subsubsection{Improve the Accessibility of the Regulator}

It was noted that independent ISPs have difficulty interacting with the CRTC. It is timeconsuming and costly to participate in CRTC hearings, and smaller companies do not have the resources to develop in-house expertise or to hire expert assistance. One small provider noted 
that it would be very useful to independents if "there was more help from the CRTC in making applications."

\subsubsection{Reduction of Regulation}

While most respondents suggested that a reasonable approach to enhancing the competitiveness of the market was to focus on more effective regulation of wholesale broadband service provision, one respondent repeatedly made the case for developing a regime with minimal regulation. His rationale was that by allowing market forces to prevail, independents and incumbents could negotiate a mutually beneficial agreement for providing access to the incumbents' facilities. Guidelines would be needed to ensure that facilities owners did provide wholesale access, but by determining the access conditions independent of the regulator, our respondent believed it would be possible to develop a more productive working relationship between incumbents and independents.

\subsubsection{Summary}

This section has identified some changes that could be made to improve the ways that independents are able to provision broadband services, with a view to increasing competitiveness in the market and thus making better broadband services available to Canadians. Although incumbents might object, the CRTC could quite easily provide some support to independent ISPs (and to the many other smaller organizations that engage with it regularly) to make the process of participating in hearings, filing complaints, and responding to other applications more accessible. The independent ISPs and some public interest groups (e.g. the Canadian Internet Policy and Public Interest Clinic) are making a case for the importance of regulating wholesale broadband access effectively as part of several current CRTC hearings, but it remains to be seen whether their arguments will be recognized and acted upon by the CRTC. Several of the recommendations would result in independents having greater control over how they provision services using an existing network. It is expected that the incumbents would resist these proposed changes in an attempt to maintain as much control as possible over their networks.

\subsection{What is the Future of Service-Based Competition in Canada?}

As noted, there is currently very little information available on the extent of service-based competition in the Canadian broadband market. In December 2009, the CRTC will hold a 
"proceeding to consider the appropriateness of mandating certain wholesale high-speed access services" (Canadian Radio-television and Telecommunications Commission, 2009c). As part of this hearing ILECs and cablecos are required to provided very detailed information on the numbers of retail and wholesale customers they serve, and the ways in which wholesale customers are accessing their networks (e.g. what percentage of wholesalers use co-location vs. aggregated wholesale DSL), as well as much additional information on how their networks are configured and responses to questions on the anticipated impacts of various regulatory changes. ${ }^{19}$ Initial filings with the Commission indicate that the respondents consider this information to be highly confidential, and will not make it all available as part of the public record of the proceedings. Nevertheless, it is anticipated that this proceeding will provide many insights on the extent of competition in the Canadian broadband market, and the independent ISPs are hoping that some of their concerns regarding access to incumbents' upgraded facilities will be addressed.

The research presented here suggests that to date, service-based competitors in Canada have not made significant investments in their own infrastructures. Given the CRTC's objective to foster facilities-based competition, it is assumed that encouraging further investment by independent ISPs is a long term goal. By using the ILECs' aggregated wholesale DSL services, market entrants are able to provide services with relatively low levels of investment (e.g. network interconnection takes place in a single location, installation of equipment in each exchange is not required), but the tradeoff is that they are subject to a variety of restrictions that impair their ability to offer differentiated services over this infrastructure. Cave (2006) suggests that over time, incentives should be increased to encourage independents to make further investments in facilities, while making continued use of the incumbents' aggregated services more difficult. Going beyond the scope of this paper, further research is needed to understand the longer term outlook for service-based competition in Canada. Questions to be addressed include:

- What are the long term prospects for independent ISPs? Do they play an important role in encouraging competitive outcomes in the market? If so, can they sustain market share? What actions, if any, are needed to help independent ISPs retain a viable market position?

\footnotetext{
${ }^{19}$ Documents related to this proceeding are online at http://www.crtc.gc.ca/PartVII/eng/2009/8663/c12_200907321.htm. The specific questions to be addressed are outlined at http://www.crtc.gc.ca/eng/archive/2009/lt090722a.htm.
} 
- Is the ladder of investment approach a good theoretical model for understanding the evolution of competition in the Canadian market, or can the market's development be better explained with other theories? What model should guide regulatory initiatives in future?

- Does it make sense to encourage independent ISP investment in facilities that may soon become obsolete, as fibre replaces copper in the customer access network? Is it feasible or desirable for independents to invest in their own fibre networks? If not, at what point should the focus shift from encouraging competition on DSL and cable networks to encouraging competition on fibre networks?

- What are the regulatory issues that must be addressed as incumbents transition to fibre networks? Should service-based competition be pursued in a fibre environment? Is open access desirable, and can it be implemented?

These questions are not unique to Canada, and are being considered in other regulatory environments (de Bijl \& Huigen, 2008; Huigen \& Cave, 2008). Nevertheless, there is a need for continued research into competition in Canada, research that can be informed by work done by organizations like the OECD (e.g. OECD Directorate for Science Technology and Industry, 2008), the European Regulators' Group (European Regulators Group, 2007), and the European Competitive Telecommunications Association (Elixmann, Ilic, Neumann, \& Plückebaum, 2008).

\section{3. Limitations}

This paper reports on research in progress, and as we continue our interviews we may uncover new insights on the nature of competition in the market that were not discussed in this paper. Additionally, it is important to offer some broader commentary on how the Canadian situation might be of interest to scholars and policy makers in other countries. This will be incorporated in future work after our interviews are completed.

As is the case in any country, the telecommunications regulatory environment, and the operations of the regulator, the CRTC, are complex. With the assistance of our informants, we have done our best to understand the details of how the Canadian wholesale broadband market operates, but there remains much to learn. It is anticipated that the outcomes of the December 2009 CRTC proceedings on the wholesale market, and the July 2009 proceedings on Internet traffic management practices will provide relevant information, information that should be considered in future studies of the nature of competition in the Canadian residential broadband 
market.

\section{Conclusion}

As Longford et al. observed in 2008, "Canadians continue to face a market oligopoly comprised of a very limited number of powerful incumbents. As a result, they live in the worst of both worlds, enjoying neither the benefits of real competition nor the benefits of an industry regulated to serve the public interest" (Longford, Moll, \& Shade, 2008, p. 5). This paper has highlighted some of the challenges faced by independent Internet service providers attempting to provide services using incumbents' networks, and demonstrates the lack of effective competition in the broadband market. The short-term prospects for Canadians hoping to gain access to more innovative, cheaper, faster broadband services are not good. Better regulatory oversight is required to achieve the goals of a competitive telecommunications sector in Canada, and to enable a variety of service providers to offer Canadians real choice in broadband services.

Canada is no longer a leader among broadband nations. There is currently no federal strategy in place to guide the development of the faster, higher quality networks that many countries now consider to be essential infrastructure for enabling communication and commerce, and for supporting their citizens' participation in the information society. There is a willing group of independent ISPs who are keen to participate in the development of improved broadband infrastructures, but without changes to the current market environment, they have limited ability to drive the development of the competitive, higher quality, faster networks that are already available elsewhere in the world.

\section{Bibliography}

Akamai (2009). The State of the Internet - 1st Quarter 2009. Cambridge, MA: Akamai. http://www.akamai.com/dl/whitepapers/akamai_state_of_the_internet_q1_2009.pdf. (accessed 15 August 2009).

Angani, P., Kim, T., Guleri, U., \& Misawa, Y. (2008). Broadband Quality Score: A Global Study of Broadband Quality. Oxford: University of Oxford/Universidad de Oviedo. http://www.sbs.ox.ac.uk/downloads/Broadband_Quality_Study_press_presentation.pdf. (accessed 29 August 2009).

Australian Competition \& Consumer Commission (2009). Fixed Services Review Declaration Inquiry for the ULLS, LSS, PSTN OA, PSTN TA, LCS and WLR: Final Decision. Canberra: Commonwealth of Australia. http://www.accc.gov.au/content/item.phtml?itemId=882454\&nodeId=c85a32b46aa23d50 6e6b67498c115562\&fn=Fixed\%20Services\%20Review\%20Declaration\%20Inquiry\%20f 
inal\%20decision\%20(July\%202009).pdf. (accessed 23 August 2009).

Baranes, E., \& Bourreau, M. (2005). An Economist's Guide to Local Loop Unbundling. Communications \& Strategies, 57(1), 13-31.

Bell (2009). DSL High Speed Access. http://www.wholesale.bell.ca/dsl.asp. (accessed 8 August 2009).

Bell Canada (2008). In the Matter of an Application by Canadian Association of Internet Providers Pursuant to Part VII of the CRTC Telecommunications Rules of Procedure and Sections 7, 24, 25, 27, 32, 36 and 62 of the Telecommunications Act Requesting Certain Orders Directing Bell Canada to Cease and Desist From "Throttling" Its Wholesale ADSL Access Services - Answer to Request for Interim Relief. http://www.crtc.gc.ca/public/partvii/2008/8622/c51_200805153/890988.zip. (accessed 29 August 2009).

Blackwell, S. (2009). Canada's Broadband Price Per Mbps - GIGO. http://www.giganomics.ca/observations-old/2009/8/20/canadas-broadband-price-permbps-gigo.html. (accessed 26 August 2009).

Bourreau, M., \& Doğan, P. (2004). Service-Based vs. Facility-Based Competition in Local Access Networks. Information Economics and Policy, 16(2), 287-306.

Canadian Radio-television and Telecommunications Commission (1999). Telecom Decision 998: Regulation under the Telecommunications Act of Cable Carriers' Access Services. http://www.crtc.gc.ca/eng/archive/1999/DT99-8.HTM. (accessed 15 April 2009).

Canadian Radio-television and Telecommunications Commission (2004). Telecom Decision CRTC 2004-24: Cybersurf Corp. V. Shaw Cablesystems G.P. - Enforcement of Telecom Decision CRTC 2003-87. http://www.crtc.gc.ca/eng/archive/2004/dt2004-24.htm. (accessed 19 May 2009).

Canadian Radio-television and Telecommunications Commission (2008a). Public Notice CRTC 2008-19: Notice of Consultation and Hearing - Review of the Internet Traffic Management Practices of Internet Service Providers http://www.crtc.gc.ca/eng/archive/2008/pt2008-19.htm. (accessed 1 June 2009).

Canadian Radio-television and Telecommunications Commission (2008b). Telecom Decision CRTC 2008-108: The Canadian Association of Internet Providers' Application Regarding Bell Canada's Traffic Shaping of Its Wholesale Gateway Access Service. http://www.crtc.gc.ca/eng/archive/2008/dt2008-108.pdf. (accessed 19 May 2009).

Canadian Radio-television and Telecommunications Commission (2009a). Communications Monitoring Report. Ottawa: Canadian Radio-television and Telecommunications Commission. http://www.crtc.gc.ca/eng/publications/reports/policymonitoring/2009/2009MonitoringR eportFinalEn.pdf. (accessed 29 August 2009).

Canadian Radio-television and Telecommunications Commission (2009b). Frequently Asked Questions: What Does the CRTC Do? http://www.crtc.gc.ca/eng/faqs.htm. (accessed 2 September 2009).

Canadian Radio-television and Telecommunications Commission (2009c). Telecom Notice of Consultation CRTC 2009-261: Proceeding to Consider the Appropriateness of Mandating Certain Wholesale High-Speed Access Services.

http://www.crtc.gc.ca/eng/archive/2009/2009-261.htm. (accessed 29 August 2009). 
Canadian Radio-television and Telecommunications Commission (2009d). Telecom Order CRTC 2009-111: Cybersurf's Application Related to the Implementation of Telecom Decision 2008-117 Regarding the Matching Speed Requirement. http://www.crtc.gc.ca/eng/archive/2009/2009-111.htm. (accessed 28 August 2009).

Canadian Radio-television and Telecommunications Commission (2009e). Telecom Order CRTC 2009-484: Bell Aliant Regional Communications, Limited Partnership and Bell Canada - Applications to Introduce Usage-Based Billing and Other Changes to Gateway Access Services. http://www.crtc.gc.ca/eng/archive/2009/2009-484.htm. (accessed 29 August 2009).

Cave, M. (2006). Encouraging Infrastructure Competition Via the Ladder of Investment. Telecommunications Policy, 30(3-4), 223-237.

Chretien, J. (2000). Connecting Canadians: Message from the Prime Minister of Canada. http://web.archive.org/web/20031212231625/www.connect.gc.ca/en/ar/1016-e.asp. (accessed 25 August 2009).

Christodoulou, K., \& Vlahos, K. (2001). Implications of Regulation for Entry and Investment in the Local Loop. Telecommunications Policy, 25(10-11), 743-757.

Coutts, R. (2008). Broadband Wireless - a Tutorial Essay. Telecommunications Journal of Australia, 58(2-3), 27.21-27.28.

de Bijl, P., \& Huigen, J. (2008). The Future of Telecommunications Regulation. Telecommunications Policy, 32(11), 699-700.

Denni, M., \& Gruber, H. (2007). The Diffusion of Broadband Telecommunications in the US: The Role of Different Forms of Competition. Communications and Strategies, 68, 139158.

Department for Culture Media and Sport, \& Department for Business Innovation and Skills (2009). Digital Britain - Final Report June 2009. Kew, Richmond, Surrey: Office of Public Sector Information. http://www.culture.gov.uk/images/publications/digitalbritainfinalreport-jun09.pdf. (accessed 16 June 2009).

Distaso, W., Lupi, P., \& Manenti, F. M. (2006). Platform Competition and Broadband Uptake: Theory and Empirical Evidence from the European Union. Information Economics and Policy, 18(1), 87-106.

Elixmann, D., Ilic, D., Neumann, K.-H., \& Plückebaum, T. (2008). The Economics of Next Generation Access - Final Report. Bad Honnef, Germany: WIK-Consult. http://www.wikconsult.com/content_e/ecta/ECTA\%20NGA_masterfile_2008_09_15_V1.pdf. (accessed 30 August 2009).

European Regulators Group (2005). Broadband Market Competition Report. http://www.erg.eu.int/doc/publications/erg_05_23_broadbd_mrkt_comp_report_p.pdf. (accessed 20 March 2009).

European Regulators Group (2007). Report on ERG Best Practices on Regulatory Regimes in Wholesale Unbundled Access and Bitstream Access. http://www.erg.eu.int/doc/publications/erg_07_53_wla_wba_bp_final_080604.pdf. (accessed 29 August 2009).

Federal Communications Commission (2009). FCC Launches Development of National Broadband Plan. http://hraunfoss.fcc.gov/edocs_public/attachmatch/DOC-289900A1.pdf. 
(accessed 12 April 2009).

Ford, G. S., Koutsky, T. M., \& Spiwak, L. J. (2007). The Broadband Performance Index: A Policy-Relevant Method of Comparing Broadband Adoption among Countries (Phoenix Center Policy Paper Number 29). Washington, DC: Phoenix Center for Advanced Legal and Economic Public Policy Studies. http://www.phoenixcenter.org/pcpp/PCPP29Final.pdf. (accessed 29 August 2009).

Governor General in Council (2006). Order Issuing a Direction to the CRTC on Implementing the Canadian Telecommunications Policy Objectives. http://canadagazette.gc.ca/archives/p2/2006/2006-12-27/html/sor-dors355-eng.html. (accessed 19 March 2009).

Höffler, F. (2007). Cost and Benefits from Infrastructure Competition. Estimating Welfare Effects from Broadband Access Competition. Telecommunications Policy, 31(6-7), 401418.

Huigen, J., \& Cave, M. (2008). Regulation and the Promotion of Investment in Next Generation Networks - a European Dilemma. Telecommunications Policy, 32(11), 713-721.

Industry Canada (1994). The Canadian Information Highway: Building Canada's Information and Communications Infrastructure. Ottawa: Supply and Services Canada.

Industry Canada (2009). Broadband Canada: Connecting Rural Canadians. http://www.ic.gc.ca/eic/site/719.nsf/eng/home. (accessed 28 July 2009).

Johnston, N., \& Aghvami, H. (2007). Comparing WiMAX and HSPA -- a Guide to the Technology. BT Technology Journal, 25(2), 191-199.

KBS World (2009). Information Ultra Highway. http://world.kbs.co.kr/english/news/news_science_detail.htm?no=4360. (accessed 24 May 2009).

Lie, E. (2003). Promoting Broadband: The Case of Canada. Geneva: International Telecommunication Union. http://www.itu.int/osg/spu/ni/promotebroadband/casestudies/canada.pdf. (accessed 29 August 2009).

Longford, G., Moll, M., \& Shade, L. R. (2008). From The "Right to Communication" To "Consumer Right of Access": Telecom Policy Visions from 1970-2007. In M. Moll \& L. R. Shade (Eds.), For Sale to The Highest Bidder : Telecom Policy in Canada (pp. 3-16). Ottawa: Canadian Centre for Policy Alternatives.

Manley, J. (1999). Speech: Canada and the Internet Revolution: Connecting Canadians. http://www.trilateral.org/annmtgs/trialog/trlgtxts/t53/man.htm. (accessed 13 August 2009).

Market Clarity (2007). Broadband Wars: The Oecd's International Broadband Arms Race. Sydney. http://www.marketclarity.com.au/freebies/OECD-BB-Wars-23-May-2007.pdf. (accessed 29 August 2009).

MTS Allstream Inc (2009). Petition to Her Excellency the Governor in Council, Pursuant to Section 12(1) of the Telecommunications Act in the Matter of Telecom Decision CRTC 2008-118, MTS Allstream Inc. - Application to Review and Vary Certain Determinations in Telecom Decision 2008-17 Regarding the Classification of Wholesale Ethernet Services and Telecom Regulatory Policy CRTC 2009-34, Request to Review and Vary Directives in Telecom Decision 2008-10 Related to the Provision of Central-Office- 
Based Wholesale ADSL Access Service and Aggregated ADSL Access Service. http://www.ic.gc.ca/eic/site/smt-gst.nsf/vwapj/crtc-2008-117-MTS-

Petition.pdf/\$FILE/crtc-2008-117-MTS-Petition.pdf. (accessed 29 August 2009).

National Broadband Task Force (2001). The New National Dream: Networking the Nation for Broadband Access. Ottawa: Industry Canada.

OECD Directorate for Science Technology and Industry (2003). Developments in Local Loop Unbundling. Paris: OECD.

OECD Directorate for Science Technology and Industry (2008). OECD Policy Guidance on Convergence and Next Generation Networks. Seoul: OECD Ministerial Meeting on the Future of the Internet Economy. http://www.oecd.org/dataoecd/14/52/40869934.pdf. (accessed 5 November 2008).

Organisation for Economic Co-operation and Development (2008). Broadband Growth and Policies in OECD Countries. Paris: OECD.

Organisation for Economic Co-operation and Development (2009a). Broadband Penetration, Historical Time Series (December 2008) http://www.oecd.org/dataoecd/63/53/41551452.xls. (accessed 26 July 2009).

Organisation for Economic Co-operation and Development (2009b). OECD Communications Outlook. Paris: OECD.

Prime Minister of Australia (2009). New National Broadband Network. http://www.pm.gov.au/media/Release/2009/media_release_0903.cfm. (accessed 10 April 2009).

Telecommunications Policy Branch (2009). Gazette Notice DGTP-004-09 - Petitions to the Governor in Council Concerning Telecom Decisions CRTC 2008-117 and CRTC 2008118, Telecom Regulatory Policy CRTC 2009-34, and Telecom Order CRTC 2009-111. Ottawa: Industry Canada. http://www.ic.gc.ca/eic/site/smt-gst.nsf/eng/sf09370.html. (accessed 29 August 2009).

Telecommunications Policy Review Panel (2006). Telecommunications Policy Review Panel Final Report 2006. Ottawa: Industry Canada.

Van Gorp, A. F., Maitland, C. F., \& Hanekop, H. (2006). The Broadband Internet Access Market: The Changing Role of ISPs. Telecommunications Policy, 30(2), 96-111.

Whalley, J., \& Curwen, P. (2008). Equality of Access and Local Loop Unbundling in the UK Broadband Telecommunications Market. Telematics and Informatics, 25(4), 280-291. 